\title{
Stress measurement for St Barbara Mines Gwalia Deeps project - one of the world's deepest underground haulage mines
}

\author{
P.M. Dight Australian Centre for Geomechanics, The University of Western Australia, Australia
}

L.A. Snyman St Barbara Limited, Australia

\begin{abstract}
Established in 1896, the Sons of Gwalia Mine orebody was successfully extracted by Bewick Moreing up until its closure in 1963. The mine had reached a depth of 1,075 m below surface and over 2.6 Moz of gold was mined during this time. The Lalor brothers purchased the mine in 1983 and open cut mining commenced one year later. The open pit was completed in 1999 reaching a depth of $285 \mathrm{~m}$ below surface. Underground mining began and reached a depth of $375 \mathrm{~m}$ below surface before the mine was once again closed in 2002 due to a low gold price and the requirement for capital to increase the depth of the mine past a low grade section. A further 1.3 Moz was mined during this time. St Barbara Ltd purchased the mine from Sons of Gwalia Ltd in 2005 and continued development of the decline beyond $375 \mathrm{~m}$. The Gwalia Deeps Mine has been planned to 1,600 metres below surface $(\mathrm{mbs})$ where it was expected that the rock strength to stress ratio based on an extrapolation of the typical stress ratio of 3:1 would produce significant stress-induced problems in the extraction horizons. An initial stress program using AE appeared to confirm the expected trend. A program of DRA testing completed in 2006, however, showed that the stress ratio at depth would be less significant with an expected stress ratio of 1.7:1. If correct this would have significant implications to the reserve which could then be pushed out to a depth of 2,000 $\mathrm{mbs}$ and the mining development. Another significant aspect is the impact of the rock mass anisotropy. During underground development the stress levels have been checked by CSIRO HI cell tests. These confirm the DRA testing to a remarkable degree. The paper will describe the approach, the results and show how the stress measurements with anisotropy explain the observations in the development drives.
\end{abstract}

\section{Introduction}

The Gwalia Deeps Mine is located south of the Leonora town site approximately $833 \mathrm{~km}$ north east of Perth in Western Australia. It is located adjacent to the NNW trending Keith-Kilkenny lineament as shown in Figure 1. The area has significant gold, nickel and copper-zinc deposits. A brief history of the mining that has occurred in the area is presented in Figure 2. Approximately $3.9 \mathrm{Moz}$ has been recovered from the mine over its history. By October 2009 the development had reached 1,233 metres below surface (mbs). In terms of tkm/month it had become the world's deepest truck haulage mine (Figure 3).

The Gwalia mineralised zone strikes $14^{\circ}$ east of magnetic north over a distance of $500 \mathrm{~m}$, dips $40^{\circ}$ to the east and plunges $45^{\circ}$ to the south-east. The mineralised zone consists of several en echelon foliation parallel lodes disposed in plan in a 'horse-shoe' shape with the 'limbs' converging at the southern end. The mineralised zone and individual lodes dip east at $35^{\circ}$ to $45^{\circ}$ and are conformable with the foliation of the Mine Sequence mafic schists. The lithological stratigraphy however, dips at $45^{\circ}$ to the east so that the precursor rock may vary from one area of the mine to another.

The individual lodes are a few metres to a few tens of metres thick defined by simple planar envelopes extensive along strike and down plunge. Internally the lodes are complexly deformed with progressive overprinting foliations and attendant intrafolial folding, potassic alteration, carbonate replacement, and quartz veining. Between the lodes are highly strained but less complexly deformed mafic schists, characterised by a planar reactivated foliation, less quartz veining and a distal less potassic alteration assemblage containing carbonate chlorite and variable biotite and sometimes amphibole. 
The mining method involves developing $5 \times 5 \mathrm{~m}$ ore drives, boring a $1.1 \mathrm{~m}$ boxhole and drilling $89 \mathrm{~mm}$ upholes as shown schematically in Figure 4. Twenty to twenty-five metre strike length stopes are mined out before paste filling either from the level or from the level above if there is top access. Levels are $20 \mathrm{~m}$ apart.

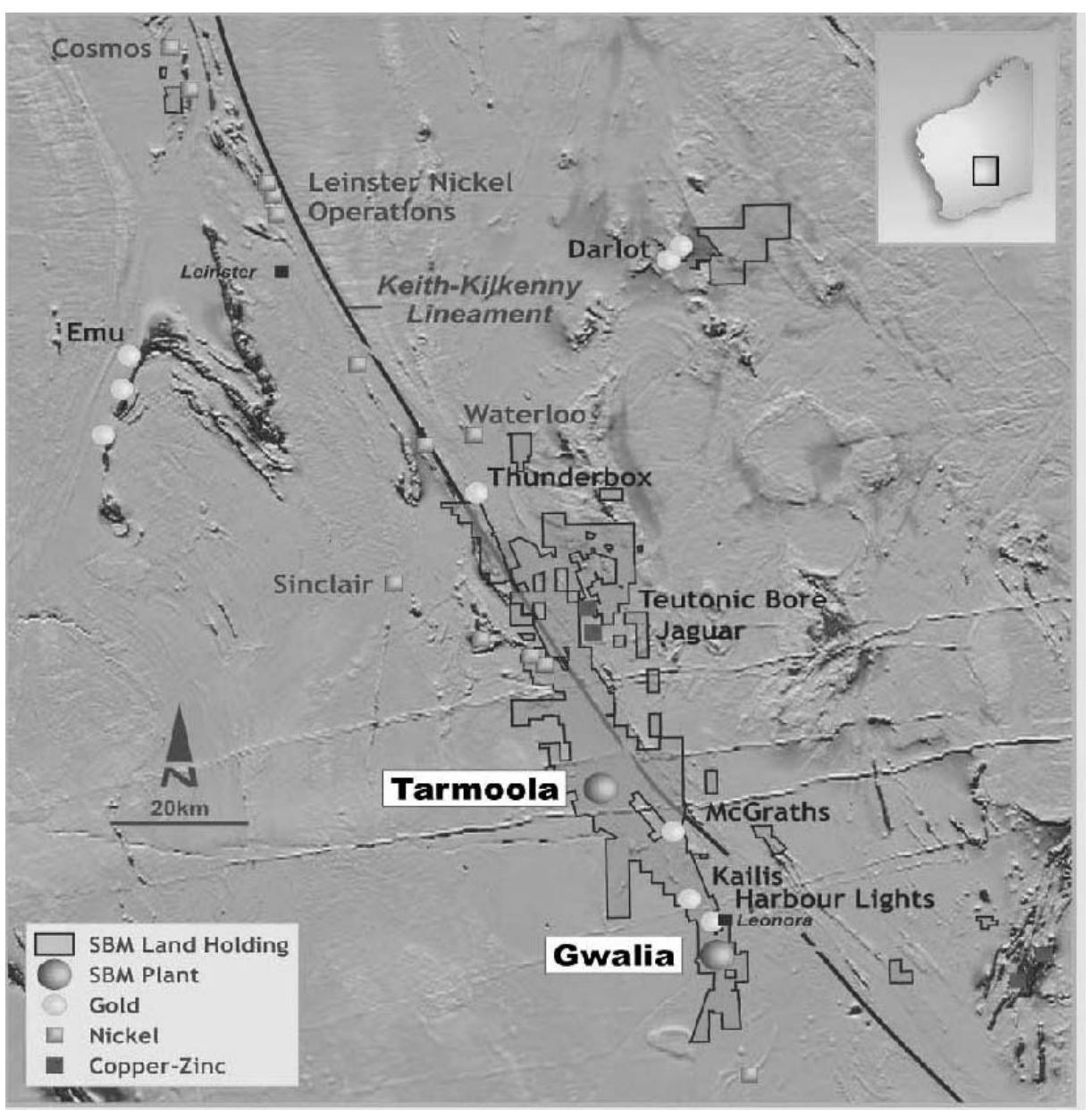

\section{Figure 1 Plan of the Leonora district - courtesy St Barbara Limited}

- 1896 - Welsh syndicate discovers the Gwalia Reef.

- 1897 - Herbert Hoover buys mine for Bewick Moreing

- 1929 - Hoover becomes $31^{\text {st }}$ President of USA

- 1963 - Mine closes 4 days before Christmas having produced more than 2.5Moz over 67 years.

- 1983 - Lalor Brothers purchase mine and open cut mining commences one year later.

- 1999 - Open pit finishes and the Hoover Decline is established for underground mining.

- 2002 - Mine put in Care and Maintenance SOG -1.3Moz

- 2005 - Mine acquired by St Barbara Ltd.

- 2008 - SBM pours first gold on Oct 2008

- 2009 - SBM first 100koz - Sept 09

Figure 2 A brief history of mining at Gwalia. The photograph is of Herbert Hoover who later became President of the US - courtesy St Barbara Limited 


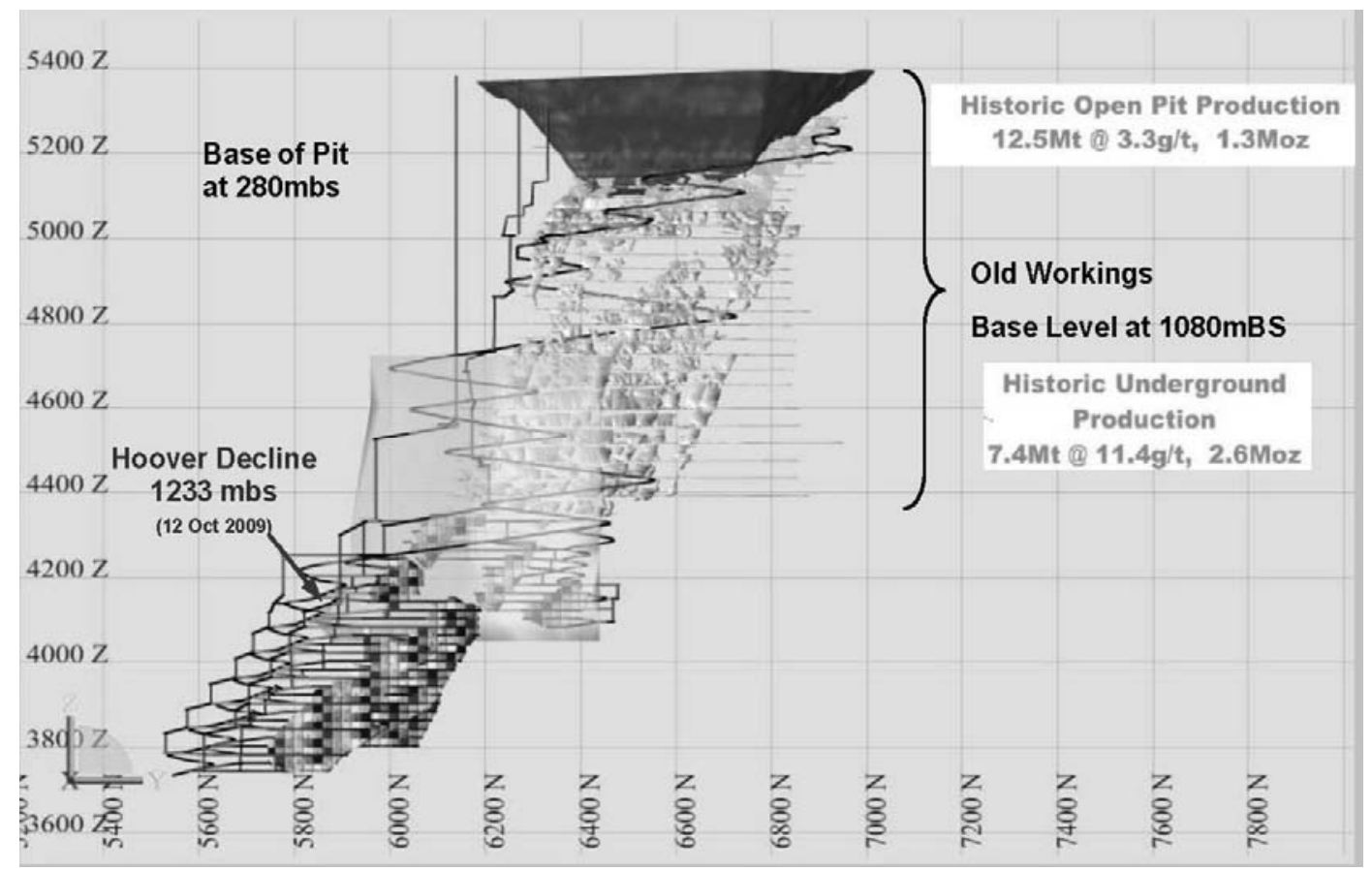

Figure 3 Schematic of the proposed underground development of the Gwalia Deeps Mine - courtesy St Barbara Limited

The ore is recovered by LHD from the ore drive as shown schematically in Figure 4.

- $5 \mathrm{~m} \times 5 \mathrm{~m}$ Ore Drive

- $1.1 \mathrm{~m}$ Boxhole slot

- 89mm Upholes

- Anfo and Emulsion

- 2900 Loader (Teleremotes)

- Trucks 50-60t Class

- Paste Fill

- Stoping above and below dyke

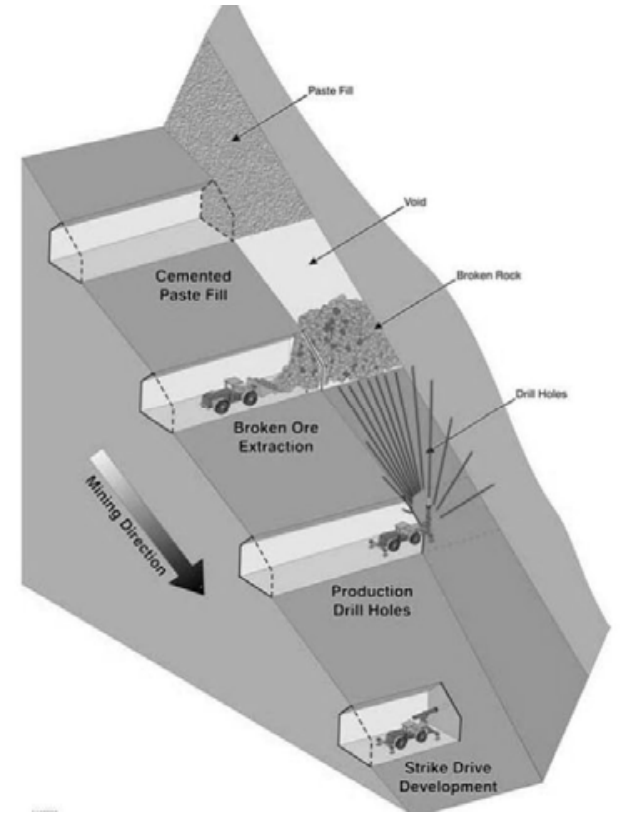

Figure 4 Proposed Mining layout - courtesy St Barbara Limited

Knowledge of the in situ stress magnitude and direction is important to mining. At Gwalia if the stress field is within the Yilgarn Trend (Lee et al., 2006) rockburst is likely below 1,200 mbs and mining very difficult below 1,600 mbs due to stress induced rock failure.

\section{In situ stress measurement}

The CSIRO HI cell is the most widely used method of stress measurement in mining and considered the most reliable (Worotnicki, 1993). It has been around for over 30 years. 
The technique is suitable when underground access is available. When this access is not available, techniques such as Hydraulic Fracture (HF) or the stress memory methods such as AE and DRA can be used. HF offers certain advantages as once the hole has been drilled many measurements can be undertaken. The difficulty with this technique is the assumption that one of the principal stresses is parallel to the axis of the borehole.

Any 'new' technique must be established against existing techniques where possible. Lambe (1973) described three types of predictions. Type A was undertaken before any knowledge of the performance was known. Type B is undertaken during the event with the results either unknown or known (B1) or Type C after the event again with the results unknown or known $(\mathrm{C} 1)$. In this case of the initial DRA work, it was undertaken on core recovered from the HI cell test. These tests were Type $\mathrm{C}$ where the results were not known. The remainder of the tests were conducted 'blind' as - Type A events.

\section{DRA technique}

Stress memory is the concept in that when a material is subjected to a load below its ultimate strength it 'remembers' the load. Commonly this has been thought of as the memory of the previous maximum stress to which the sample was loaded (Kaiser, 1953). A significant amount of testing has been undertaken using acoustic emission to identify The Kaiser Effect (e.g. Kanagawa et al., 1976; Kurita and Fujii, 1979, Villaescusa et al., 2003). It has been successful in laboratory tests but there has been uncertainty for the determination of in situ stress where the maximum stress is unknown (Lavrov, 2002).

Yamamoto et al. (1990) determined that the maximum previous stress could be identified using the Deformation Rate Analysis (DRA). Simply stated, this says that the previous stress level in a sample can be detected by determining the strain difference between two successive cycles of loading (known then as the inelastic strain). Mathematically this is expressed as:

$$
\Delta \varepsilon_{\mathrm{ij}}(\sigma)=\varepsilon_{\mathrm{j}}(\sigma)-\varepsilon_{\mathrm{i}}(\sigma) \ni \mathrm{j}>\mathrm{i}
$$

Dight (2002) showed that using the DRA technique, analysis of the stress/ strain difference $\left(\sigma / \Delta \varepsilon_{1 \varphi}\right)$ graphs for a series of tests each load applied to a sample could be determined, not just the previous maximum load. This was based on the work of Meyers et al. (2002) and could be observed in the work of Seto and Villaescusa (1999). Hence by careful examination of the results, the magnitude of one of the principal in situ stresses aligned along the axis of the sample (knowing the orientation of the sample in 3D space) could be determined.

The DRA technique remembers the in situ stress (known as DRA IS) as well as the Kaiser Effect (designated as DRA KE). The latter could be induced by the stress changes occurring in the rock just ahead of coring due to the in situ stress as shown by Dight (2006) and Lim et al. (2006).

The DRA measurements have now been independently verified in Type A testing at a number of mine sites using HI cell, borehole slotter, USBM cell, and Type C testing using hydraulic fracture.

\section{$4 \quad$ Samples}

For Gwalia Deeps, the core samples for DRA tests were sourced from five locations. Each represents a portion of a mafic unit which overlays the upper contact of the Gwalia Lode Sequence. Cores were marked with a line along the core axis and arrow marks indicating the end of the hole direction.

The core samples were recovered from five geotechnical holes. The holes were HIDD, GWDD8H, GWDD7E, GWDD12 and GWDD12A. The HIDD cores were from the two holes used to conduct the Hollow Inclusion (HI) test programme. HIDD1 was a solid core while HIDD2 was a section encapsulating a HI stress sensor. Both the cores were from the horizontal holes drilled to Mine Grid $360^{\circ}$ and located at $282 \mathrm{~m}$ below surface.

Samples GWDD8H were from a surface diamond hole of $50 \mathrm{~mm}$ diameter NQ2 core recovered from intervals of 1,238.3-1,240.08 $\mathrm{m}$ and 1,241.95-1,242.33 $\mathrm{m}$ approximately $1,127 \mathrm{~m}$ below the surface. The hole was oriented at $56.1^{\circ}$ towards Mine Grid $240.6^{\circ}$. 
Samples GWDD7E were recovered from diamond hole of NQ2 core from intervals of 1,507.1-1,509 m. The hole was oriented at $-68.6^{\circ}$ towards Mine Grid $205^{\circ}$. The intersection was approximately $1,434 \mathrm{~m}$ below surface.

Samples GWDD12 were from a downhole depth of $1,840 \mathrm{~m}$ which was oriented at $-55.4^{\circ}$ towards $254.6^{\circ}$ Gwalia Mine Grid. The equivalent depth below the surface was 1,697 $\mathrm{m}$.

Samples GWDD12A were recovered from a downhole depth of $1,834 \mathrm{~m}$. The hole was oriented at $-52.5^{\circ}$ towards $265.3^{\circ}$ Gwalia Mine Grid approximately $1,704 \mathrm{~m}$ below the surface.

All sub sampling and sample preparation was undertaken by Coffey Mining materials testing laboratory. Sub sampling was undertaken by under coring the oriented core recovered from the test site. The orientations of the under core relative to the bottom of core mark (trend and plunge) are:

- $000 / 90$

- $000 / 45$

- $000 / 00$

- $270 / 45$

- $270 / 00$

- $225 / 00$.

The true orientation of the samples in space is then calculated from the orientation and survey of the hole.

The core diameter is typically $18-20 \mathrm{~mm}$. The sub sample length is $40-50 \mathrm{~mm}$ (depending on the original core diameter). End planarity is specified to be within $0.02 \mathrm{~mm}$ according to the ISRM specification on end preparation for UCS testing but better than this tolerance is achieved. The test samples are measured for compliance with a strict requirement for parallelism.

Samples are strain gauged to obtain the stress-strain relationship. Samples are tested axially without confinement and the test can be conducted in a strain controlled machine or a stress controlled machine. The test program requires two load cycles from which the strain difference is calculated. Results for the full load/unload cycle are recorded and the results are analysed and interpreted.

\section{$5 \quad$ Stress measurement}

At Gwalia Deeps even though mining had previously reached $1,135 \mathrm{mbs}$ before closure of the original underground mine in 1963, access was no longer available due to an underground collapse. The initial stress measurements using the $\mathrm{HI}$ technique were undertaken in 2006 at $282 \mathrm{mbs}$. At that time there were two AE measurements that had been undertaken as part of the MERIWA Project (Villaescusa et al., 2003). The maximum principal stress for the HI, AE and DRA results are shown in Figure 5. Also shown on the chart is the design assumption based on the Yilgarn Trend (after Lee et al., 2006) and a plot showing the 2/3 UCS $(110 \mathrm{MPa})$ as an indicator of possible rockburst conditions.

The stress results for the DRA clearly indicate much lower stress magnitudes than had previously been considered for the Yilgarn Block (Lee et al., 2006). Figure 6 shows the deviatoric stress for a number of projects in the Yilgarn (Junction, Bounty, Mt Charlotte and Big Bell) and a comparison with mines in Canada (Craig Mine, Kidd Creek and LaRonde). Also shown on the graph are the results from the DRA IS testing indicating that Gwalia Deeps was more likely to behave like the Canadian Mines. As a consequence the mine arranged more stress measurements as the implication would be significant. A lower stress field would possibly release more reserve at depth. 


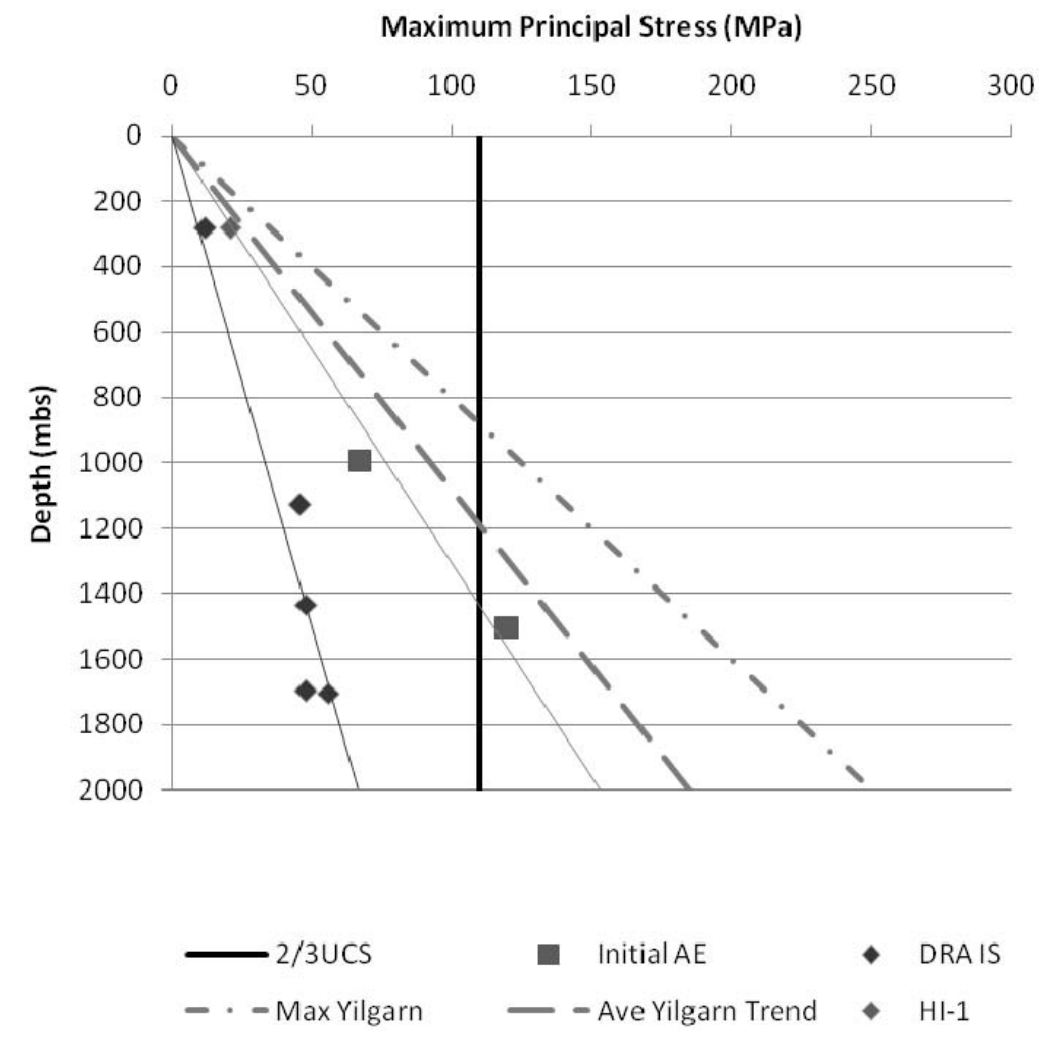

Figure 5 Stress interpretations 2006. The DRA analysis at 282 mbs was performed blind on overcore from the HI cell tests. The AE results were from the initial MERIWA investigation (Villaescusa et al., 2003)

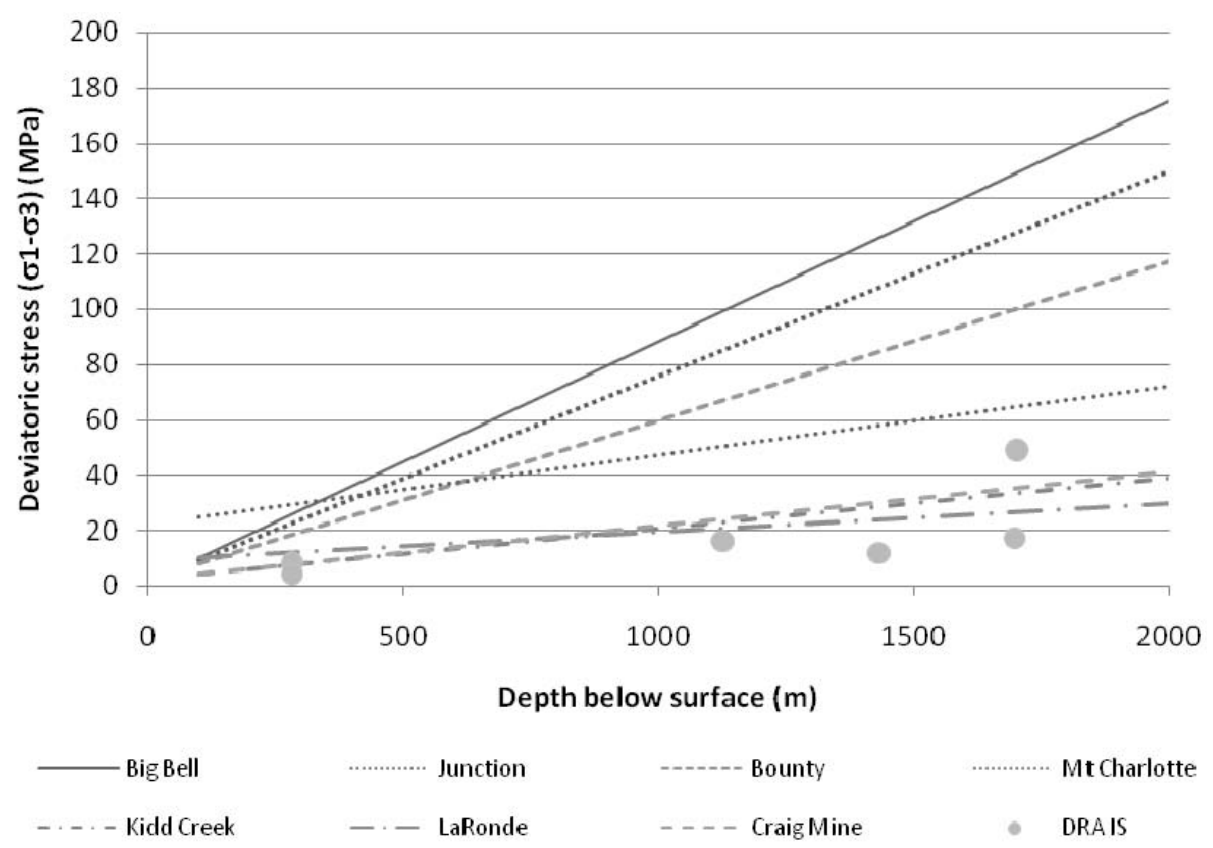

Figure 6 Deviatoric stress magnitude with depth for mining provinces in Western Australia and Canada. Also shown are the deviatoric stress measurements using the DRA IS for Gwalia Deeps 
In 2006, the assumed stress gradient (ignoring DRA) was:

- $\quad \mathrm{AE}$ and HI, $\sigma_{1}=0.073 * \mathrm{z}$

- Yilgarn average, $\sigma_{1}=0.093 * \mathrm{z}$.

In either case, the projected depth of mining without rockburst would be between 1,200 and 1,425 mbs.

The stress gradient for the DRA IS (in situ stress) was:

- $\quad$ DRA $-\sigma_{1}=0.033^{*} \mathrm{z}$.

By late 2009, with the additional HI cell measurements and new AE testing it was clear that the DRA had provided a robust stress measurement prediction (Figure $7 \mathrm{a}$ ). Figure $7 \mathrm{~b}$ shows the deviatoric stress also confirming the same trend identified by the DRA IS.

The principal stress gradient based on the HI cells alone is:

- $\quad \mathrm{HI} \sigma_{1}=0.042 * \mathrm{z}$.

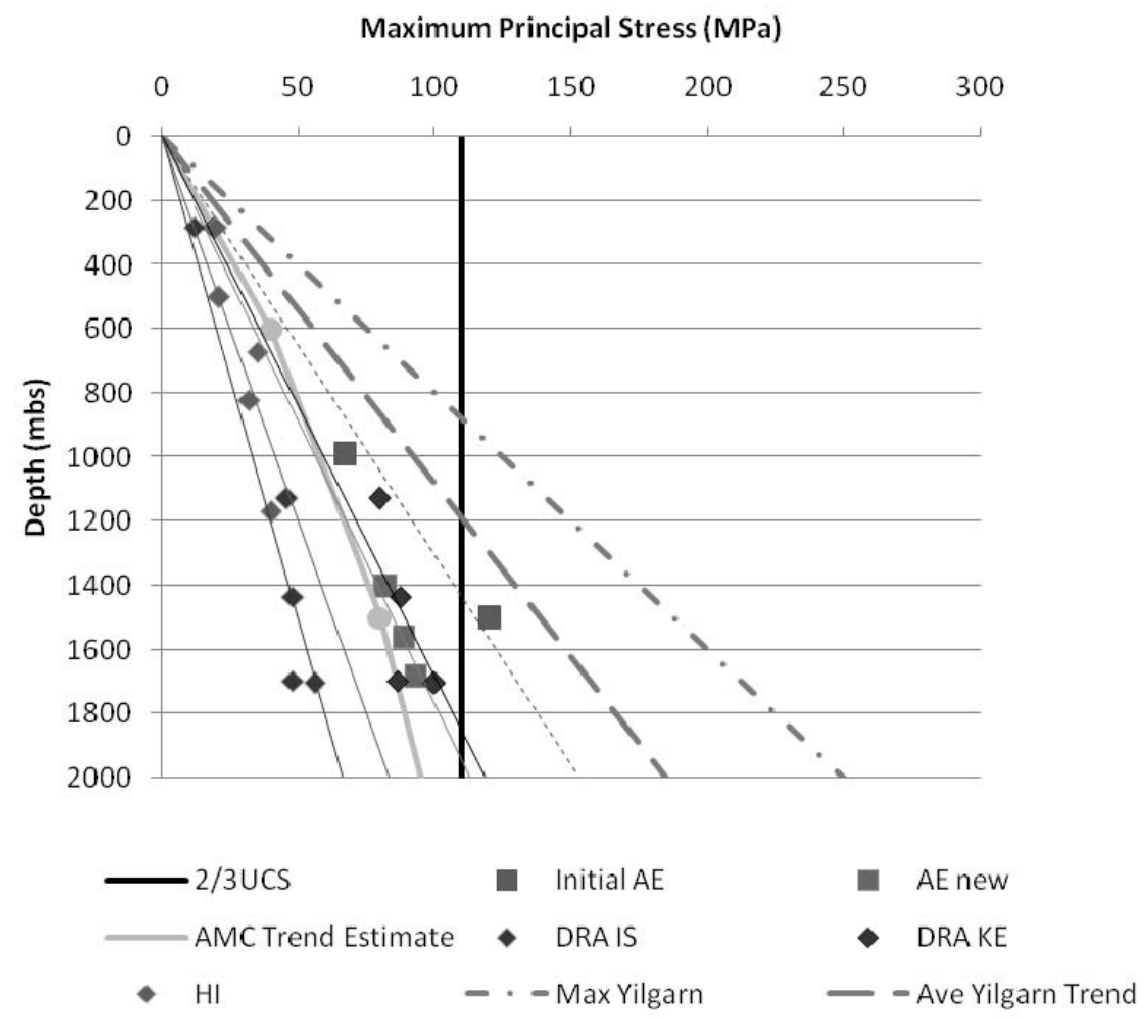

Figure 7a Stress measurements 2009 and design assumptions. Mining could progress to at least 2,500 mbs before rockburst was a consideration based on the HI tests and DRA IS results. The DRA KE results and the AE new results give similar results for the Kaiser Effect based on the trend lines for both results - stress results provided courtesy of St Barbara Limited 


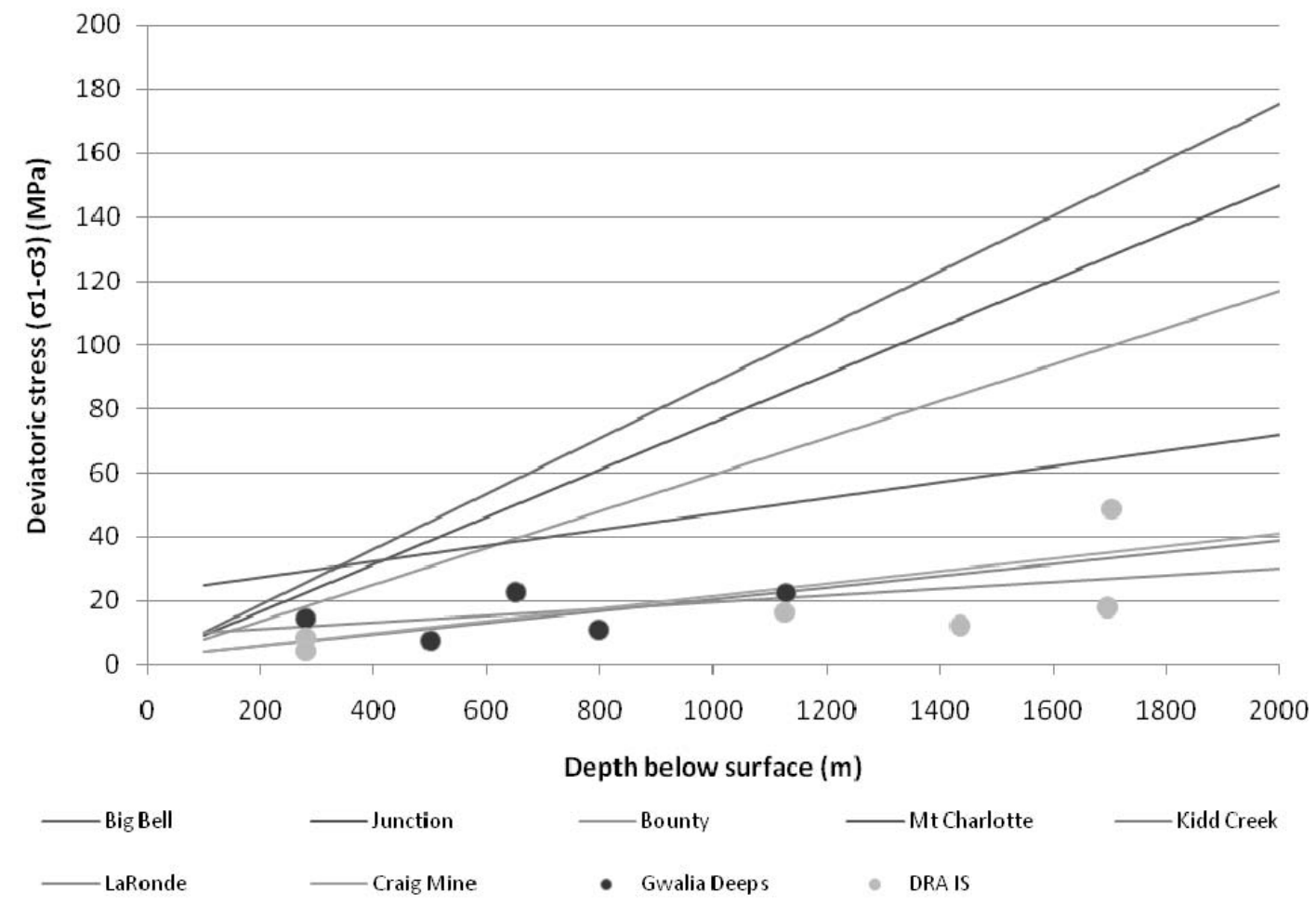

Figure 7b Deviatoric stress magnitude with depth for mining provinces in Western Australia and Canada. Also shown are the deviatoric stress measurements using the $\mathrm{HI}$ cell measurements and the DRA IS for Gwalia Deeps

It is now apparent that if the ore continues mining could progress to at least $2,500 \mathrm{mbs}$ or even further. This does not mean that other stress induced problems may not be encountered in the schistose rock as discussed below.

The DRA KE and the later AE results are very similar in magnitude. This would be expected as both methods can measure the Kaiser Effect.

The difference between the HI results and the DRA IS results is much closer than any other method proposed. Of significance from a fundamental proof of technique, the DRA IS results were achieved three years earlier as Type A tests (Lambe, 1973).

The principal stress orientations resolved by these methods differ and this has not yet been resolved. One consideration is that anisotropy appears to play a role in HI stress measurement. For HI measurements Worotnicki (1993) considered that this was not an issue if the modulus difference was less than $20 \%$. Amadei (1996) disagreed and claimed that a difference as small as $14 \%$ could affect the HI results. The anisotropy is relevant to the local measurement. In the case of the HI cell the strain gauges are $25 \mathrm{~mm}$ long and the hole diameter is $38 \mathrm{~mm}$. If the modulus is different in the local area, then this needs to be taken into consideration (e.g. Hakala et al., 2006, 2007).

One benefit of the DRA measurements is that the modulus and Poisson's Ratio in six directions can be determined as part of the test (Dight and Dyskin, 2007, 2008). With due consideration the HI cell measurements could be examined using the anisotropic parameters to determine what if any effect it has on the magnitude and direction.

\section{$6 \quad$ Stress observations and modelling}

As a consequence of the DRA approach (which can be combined with AE and seismic velocity), the modulus and Poisson's ratio are measured on each subsample. Assuming that the modulus can act as a vector, then the modulus can be resolved in three principal directions. The parameters can then be used in stress analysis programs to better understand the 3D aspects of the rock mass and how it affects mine development and 
stoping. There is very little visual expression of stress underground at Gwalia which is further confirmation of the low stress field measured by DRA and confirmed by HI cell measurements. There is no observed breakout on raisedrill or blast holes and no evidence of core disking. Monitoring has shown that there is minimal convergence in development drives and stress induced failures are rare. This makes back calculation of stress from failure observation uncommon. However, one such example did occur at a development heading at $1,180 \mathrm{mbs}$ in 2009 , which could be attributed to the effect of the anisotropic modulus. This provided a good opportunity for back calculation.

The DRA IS measurements have been used in conjunction with the anisotropic elastic modulus and Poisson's Ratio to interpret the stress induced movements observed underground at the $1,180 \mathrm{mbs}$ drive.

Table 1 Parameters for the stress analysis at $1,180 \mathrm{mbs}$

\begin{tabular}{llll}
\hline Stress & Trend & Plunge & MPa \\
\hline$\sigma_{1}$ & 240.4 & 25.8 & 46.2 \\
$\sigma_{2}$ & 349.7 & 34.4 & 41 \\
$\sigma_{3}$ & 122 & 44.5 & 29.8 \\
\hline & & & \\
\hline Modulus & Trend & Plunge & $\mathbf{G P a}$ \\
\hline $\mathrm{E}_{1}$ & 353.9 & 12.6 & 132.2 \\
$\mathrm{E}_{2}$ & 97.3 & 46 & 111.3 \\
$\mathrm{E}_{3}$ & 252.6 & 41.2 & 76.1 \\
\hline
\end{tabular}

Observations of stress induced movement and crushing have been made at the 1,180 mbs level as shown in Figure 8 . The results of the stress measurement at $1,127 \mathrm{mbs}$ level are shown in Table 1 . The input to the stress analysis is shown in Figure 9.

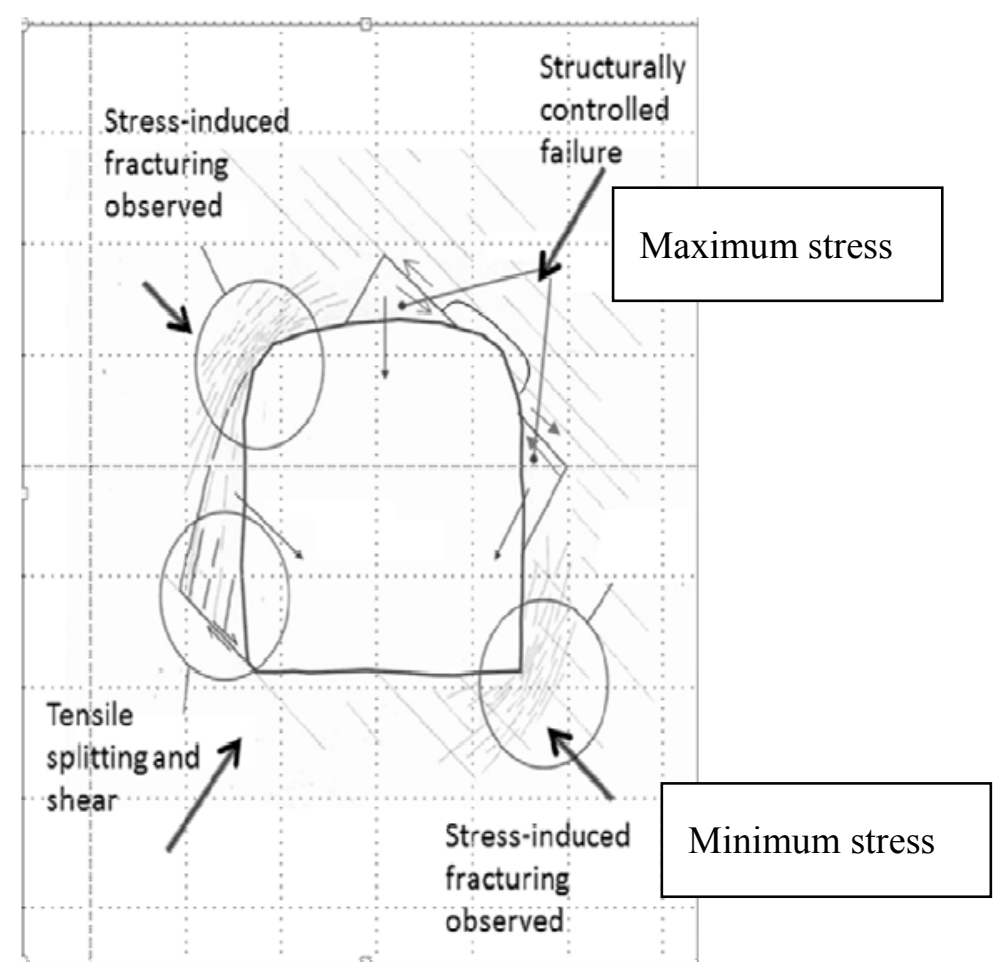

Figure 8 Interpretation of observations at 1,180 mbs ore drive looking north - after Mike Sandy, AMC Consultants 


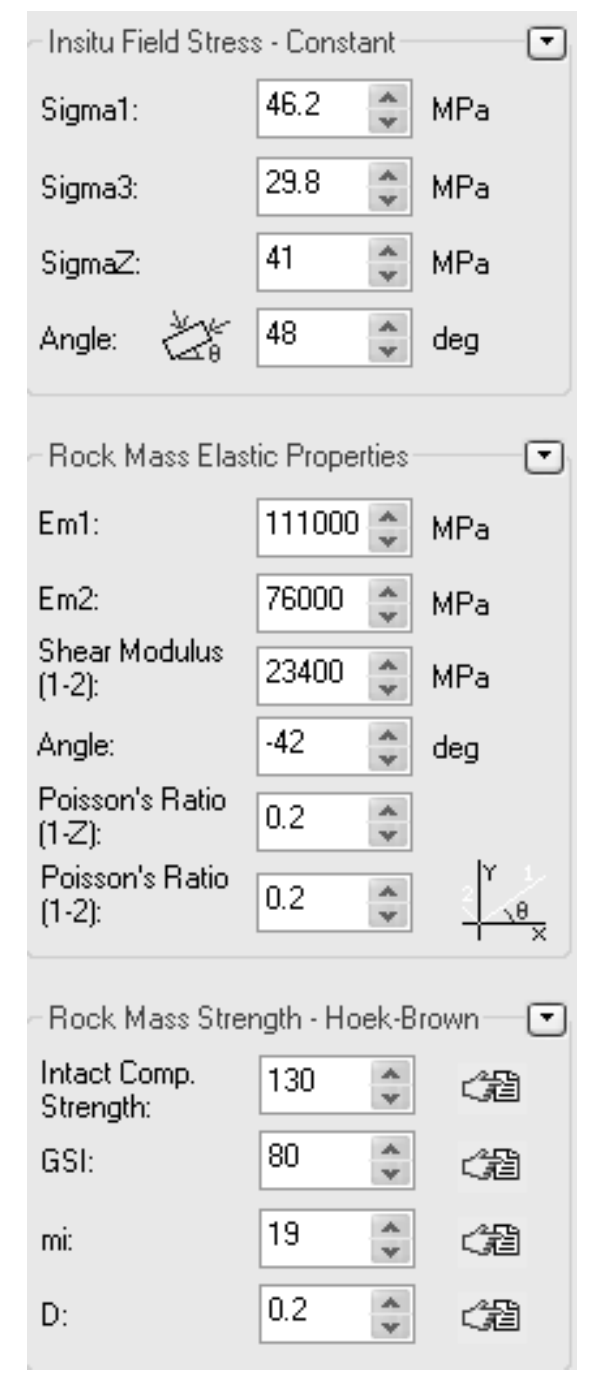

Figure 9 Table of the stress and material parameters used in the stress analyses for 1,180 mbs ore drive

Using the stresses measured using DRA IS and the anisotropic parameters; the results are shown in Figure 10 using Phases ${ }^{\circledR}$ and Figure 11 using Examine2 $D^{\circledR}$ from Rocscience. The simple interpretation of the stress concentrations and stress relaxations coincide well with the observations underground. The results are sensitive to the anisotropic stress ratio.

\section{$7 \quad$ Summary and conclusion}

The introduction of any 'new' stress measurement technique requires extensive testing under a variety of conditions. At Gwalia Deeps the DRA IS measurements have been checked independently by examining the stress measured by the HI cell and a USBM cell. The DRA KE agrees in magnitude with the AE as both measure the maximum stress to which the core has been subjected (i.e. the Kaiser Effect). The DRA IS prediction of the expected stress field was made in 2006. It has successfully predicted the stress field ahead of subsequent HI cell testing.

Both programs were conducted blind (Lambe, 1973) and the results are encouraging. Further work will be undertaken to understand all the implications.

As a consequence of the DRA approach, the modulus and Poisson's ratio are measured on each subsample. These parameters can be used to undertake stress analysis where anisotropy could be an issue and also used to reinterpret HI cell test results where this is deemed an influencing factor. 


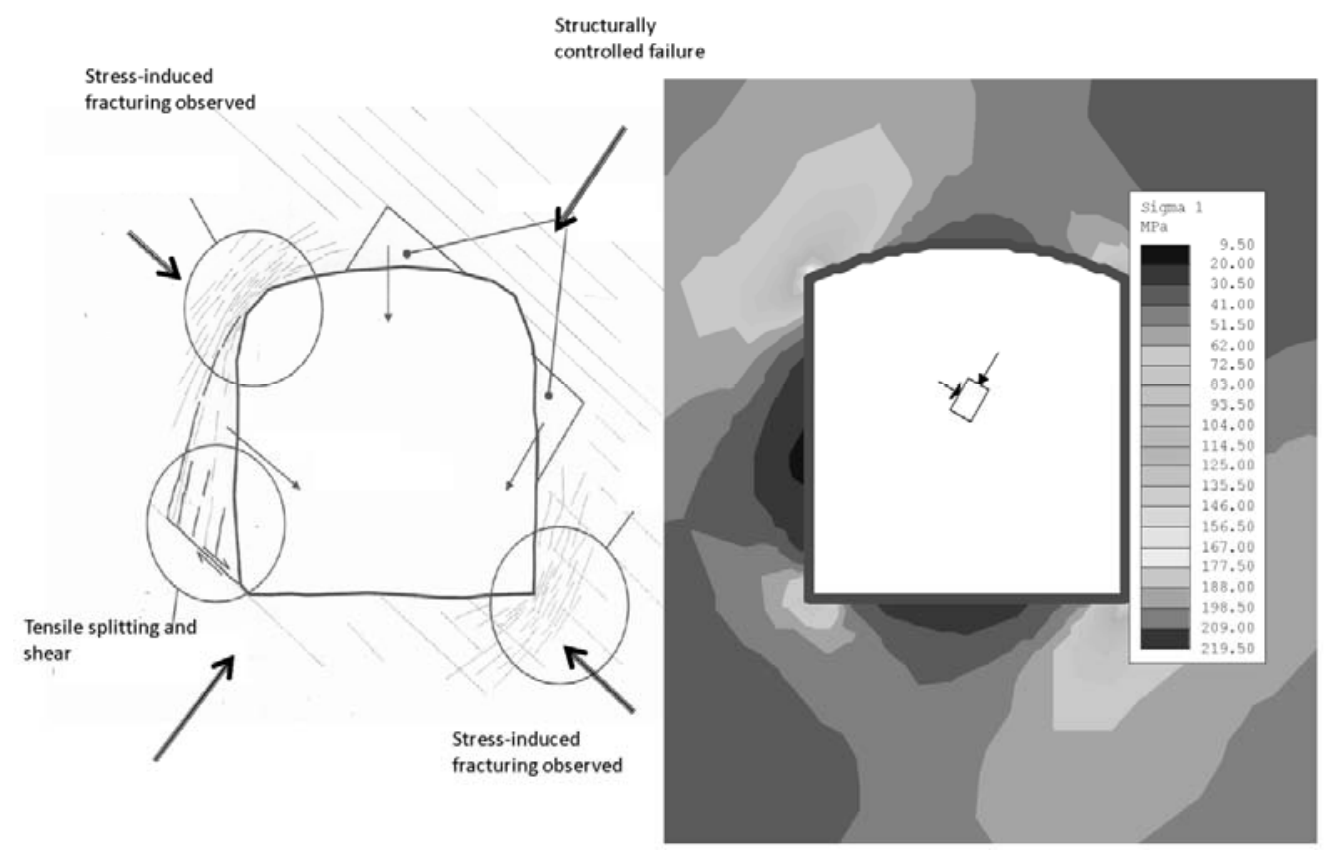

Figure 10 Using Phases ${ }^{\circledR 7} 7$ and anistropic parameters the stress concentrations and stress relaxation match the observations. The in situ stresses are the pre-mining stresses

\section{Using BE and Anisotropy}

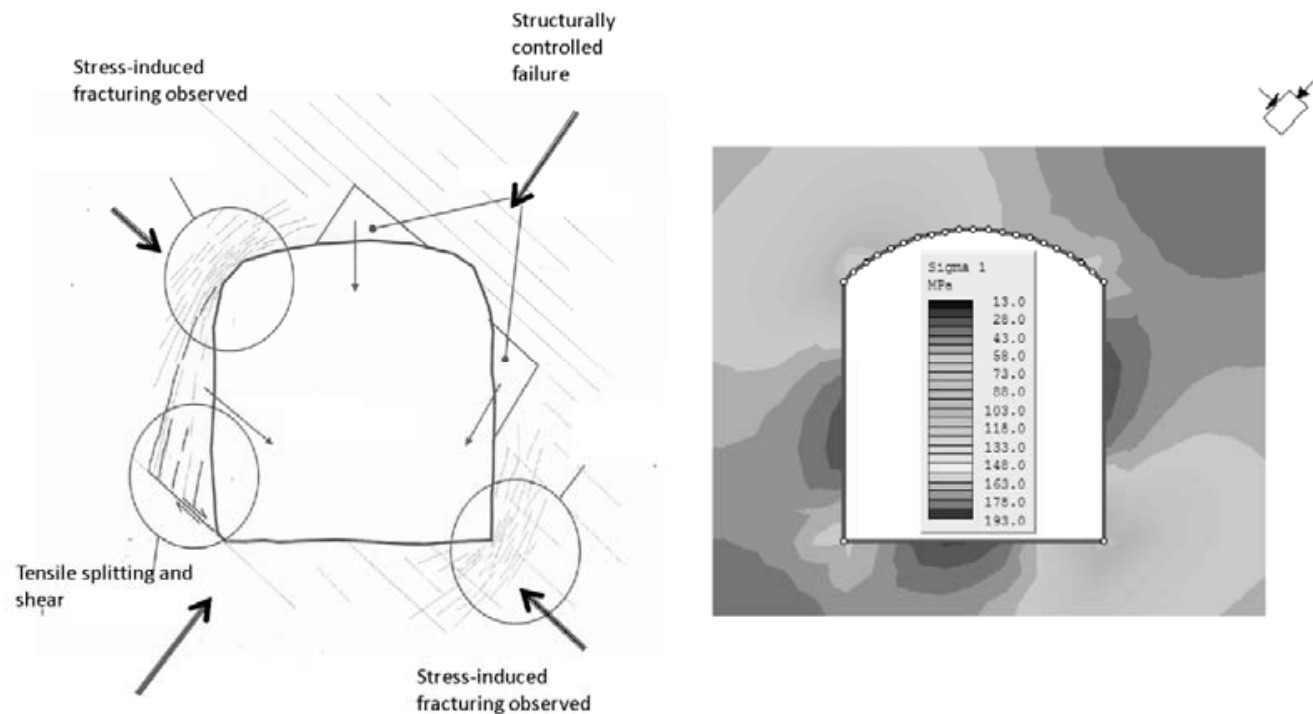

Gwalia Deeps looking north - after Mike Sandy AMC

Figure 11 Using Examine2d ${ }^{\circledR}$ and anistropic parameters the stress concentrations and stress relaxation match the observations. The in situ stresses are the pre-mining stresses

\section{Acknowledgements}

The work reported here has had many participants. The first author would like to acknowledge the support of Ian Hulls and Sudeep Pant at Coffey Mining, Arcady Dyskin and Boris Tarasov at University of Western 
Australia, Martin Reed formerly of St Barbara Limited, and St Barbara Limited for permission to publish this paper.

\section{References}

Amadei, B. (1996) Importance of anisotropy when estimating and measuring in-situ stress in rock, Int. J. Rock Mech. Min. Sci. Vol. 33(3), pp. 293-325.

Dight, P.M. (2002) In situ stress determination for Argyle Block Cave, Report to Rio Tinto - BFP Consultants unpublished.

Dight, P.M. (2006) Determination of In situ Stress from Oriented Core, in Proceedings International Symposium on In Situ Rock Stress (Trondheim, Norway, June 18-24, 2006), International Society for Rock Mechanics.

Dight, P.M. and Dyskin, A. (2007) Accounting for the effect of rock mass anisotropy in stress measurements, in Proceedings Fourth International Seminar on Deep and High Stress Mining (Deep Mining07), Y. Potvin (ed), 7-9 November 2007, Perth, Australia, Australian Centre for Geomechanics, Perth, pp. 415-424.

Dight, P.M. and Dyskin, A. (2008) On the Determination of Rock Anisotropy for Stress Measurements, in Proceedings First Southern Hemisphere International Rock Mechanics Symposium (SHIRMS), Y. Potvin, J. Carter, A. Dyskin and R. Jeffrey (eds), 16-19 September 2009, Perth, Australia, Australian Centre for Geomechanics, Perth, Vol. 2 - Fundamental and Petroleum, pp. 575-586.

Hakala, M., Kuula, H. and Hudson, J.A. (2007) Estimating the transversely isotropic elastic intact properties for in-situ stress measurement data reduction: A case study of the Olkiluoto mica gneiss, Finland, Int. Jnl. Rock Mechanics and Mining Sciences, Vol. 44, pp. 14-46.

Hakala, M., Sjöberg, J., Hudson, J.A., Christiansson, R., Johansson, E. and Riikonen, S. (2006) Quality control and interpretation of in situ measurement data, in Proceedings International Symposium on In Situ Rock Stress (Trondheim, Norway, June 18-24, 2006), International Society for Rock Mechanics.

Kaiser, J. (1953) Erkenntnisse und Folgerungen aus der Messung von Geräuschen bei Zugbeanspruchung von metallischen Werkstoffen, Archiv für das Eisenhüttenwesen, pp. 43-45.

Kanagawa, T., Hayashi, M. and Nakasa, H. (1976) Estimation of spatial geostress components in rock samples using the Kaiser effect of acoustic emission, Rep. No. 375017, Central Res. Inst. of Electrical Power Industry, Abiko, Japan.

Kurita, K. and Fujii, N. (1979) Stress memory of crystalline rocks in acoustic emission, Geophys. Res. Lett., Vol. 6, No. 1, pp. 9-12.

Lambe, T.W. (1973) Predictions in soil engineering, Geotechnique, Vol. 23, pp. 149-202.

Lavrov, A. (2002) The Kaiser effect in rocks: principles and stress estimation techniques, Int. J. Rock Mech. Min. Sci., Vol. 40, pp. 151-171.

Lee, M.F., Mollison, L.J., Mikula, P.M. and Pascoe, M.J. (2006) In situ rock stress measurements in Western Australia's Yilgarn Craton, in Proceedings International Symposium on In Situ Rock Stress (Trondheim, Norway, June 18-24, 2006), International Society for Rock Mechanics.

Lim, S.S., Martin, C.D. and Christiansson, R. (2006) Estimating in-situ stress magnitudes from core disking, in Proceedings International Symposium on In Situ Rock Stress (Trondheim, Norway, June 18-24, 2006), International Society for Rock Mechanics, pp. 159-166.

Meyers, A.G., Hunt, S.P. and Oliver, K.J. (2002) The use of the DRA technique and porosimetry for estimating the maximum in-situ stress in rock from core, Australian Geomechanics Journal, Vol. 37(1), pp. 17-22.

Seto, M. and Villaescusa, E. (1999) In situ stress determination by acoustic emission techniques from McArthur River Mine core, in Proceedings 8th Australia New Zealand Conference on Geomechanics, Hobart, Vol. 2, pp. $929-934$.

Villaescusa, E., Windsor, C., Li, J., Baird, G. and Seto, M. (2003) Stress Measurements from cored rock, MERIWA Report M329.

Worotnicki, G. (1993) CSIRO triaxial stress measurement cell, in Comprehensive Rock Engineering, J.A. Hudson (ed), Vol. 3, Pergamon Press, Oxford, pp. 329-394.

Yamamoto, K., Kuwahara, Y., Kato, N. and Hirasawa, T. (1990) Deformation rate analysis: a new method for in-situ stress estimation from inelastic deformation of rock samples under uniaxial compression, Tohoku Geophysical Journal, Vol. 33, pp. 1-13. 